\title{
Um acervo, uma coleção e três problemas: a Coleção Jacques Pilon da Biblioteca da FAUUSPI
}

\section{Joana Mello de Carvalho e Silva ${ }^{2}$}

RESUMO: Este artigo examina a constituição do Acervo de Projetos de arquitetura da Biblioteca da Faculdade de Arquitetura e Urbanismo da Universidade de São Paulo (FAUUSP), o tratamento da Coleção Jacques Pilon e os rendimentos do projeto de arquitetura como fonte documental a partir de três questões interligadas: a constituição do campo arquitetônico no Brasil; a história de São Paulo e sua arquitetura; e a contribuição dos arquitetos estrangeiros para a construção da cidade entre 1930 e 1960. A partir da abordagem de novas e velhas fontes de pesquisa, procura-se articular a história da arquitetura com outros campos do conhecimento nem sempre a ela relacionados, mas que juntos podem contribuir para uma leitura mais complexa da produção arquitetônica e para os esforços de revisão da historiografia da arquitetura moderna no Brasil.

PALAVRAS-CHAVE: Jacques Pilon. Arquivo. Documento. Projeto de arquitetura. Acervo FAUUSP.

ABSTRACT: This article examines the establishment of the Archive of Projects of the Library of the Faculty of Architecture and Urbanism of the University of Sao Paulo (FAUUSP), the treatment of the Collection Jacques Pilon and the architectural design as a documentary source from three interconnected issues: the constitution of the architectural field in Brazil; the history of São Paulo and its architecture and the contribution of foreign architects to build the city between the years 1930 and 1960. From the approach of new and old sources of research, this article seeks to articulate the History of Architecture with other fields of knowledge not always related to it, but that together it can contribute to a more complex reading of architectural production and to efforts of reviewing the historiography of modern architecture in Brazil.

KEYWORDS: Jacques Pilon. Archive. Document. Architectural Design. FAUUSP collection.
1. Versões reduzidas deste artigo foram apresentadas, em 2014, no III Enanparq - Arquitetura, cidade e projeto: uma construção coletiva (2014) e, em 2015, no XXVIII Simpósio Nacional de História, promovido pela Associação Nacional de História (ANPUH-Brasil) para o qual contamos com $\mathrm{o}$ apoio financeiro da $\mathrm{Fa}-$ pesp. Agradeço aos comentários de Paulo Garcez, Ana Castro, Letícia Borges Nedel e Luciana Quillet Heymann, que auxiliaram no desenvolvimento das questões aqui tratadas.

2. Docente da Faculdade de Arquitetura e Urbanismo (FAU) da Universidade de São Paulo (USP). E-mail: joana-mello@usp.br. 
3. O nome acervo e não arquivo foi adotado pelo fato de os documentos que o compõem pertencerem originalmente ao patrimônio de um arquiteto e seu escritório e por estarem guardados dentro de uma biblioteca.

4. A tese foi defendida em 2010 com apoio da Fapesp e publicada pela Annablume, com auxílio da mesma fundação, em 2012.

5. A noção de campo aqui empregada apoia-se em Pierre Bourdieu, que a define em função da autonomia de um determinado espaço social - cultural, econômico, educacional, científico, disciplinar etc. -, no qual se estabelecem relações de concorrência e disputa pelo domínio do sistema de relações de produção, circulação e consumo de bens simbólicos (BOURDIEU, 1974a, 1974b, 1989a, 1989b).
Introdução

Este artigo trata de um acervo, ${ }^{3}$ uma coleção e três problemas, a partir da experiência com a documentação do Acervo de Projetos da Biblioteca da Faculdade de Arquitetura e Urbanismo da Universidade de São Paulo (FAUUSP), desenvolvida durante a tese de doutorado denominada $\bigcirc$ arquiteto e a produção da cidade: a experiência de Jacques Pilon em perspectiva (1930-1960). ${ }^{4}$ Pensando em como se deu a constituição do campo ${ }^{5}$ arquitetônico no Brasil no século XX, em como o processo de metropolização de São Paulo se desenvolveu em termos urbanísticos e arquitetônicos e em qual seria a contribuição dos arquitetos estrangeiros para a construção da cidade entre os anos de 1930 e 1960, pretende-se aqui recuperar o movimento dialético entre esses problemas históricos e os fundos documentais trabalhados (MENESES, 2003), notadamente os projetos de arquitetura realizados pelos escritórios do arquiteto francês radicado em São Paulo Jacques Émile Paul Pilon (1905-1962).

Na história da arquitetura, o projeto é sem dúvida o documento mais recorrente. É preciso atentar, contudo, para o dado de que seus suportes e sentidos variam conforme a concepção da arquitetura daquele que o produziu e também de acordo com a problemática histórica formulada pela pesquisa que o toma como documento. Em abordagens que privilegiam a análise da forma arquitetônica, a autoria e o saber disciplinar específico, o suporte documental preferencial são os desenhos produzidos para publicação, cujo objetivo é o de enfatizar as intenções dos arquitetos na organização dos espaços, suas soluções plásticas e técnico-construtivas. Em trabalhos que, como este, procuram investigar as relações entre cultura e sociedade a partir da perspectiva da história e da sociologia cultural (SCHORSKE, 1988; CHARTIER, 1990; BAXANDALL, 1991; BOURDIEU, 1974a, 1974b, 1989a, 1989b), o projeto é entendido como um constructo sócio-histórico, fruto de agentes diversos e inseparável da sociedade que o produziv e, por isso, não apenas o resultado do trabalho isolado do arquiteto em seu escritório. De fato, ao realizarem um projeto, os arquitetos mobilizam princípios que orientam a sua prática, ao mesmo tempo que lidam com um conjunto de fatores que extrapolam os limites do campo profissional, tensionando a sua validade, seja por adaptação, seja por radicalização. Nessa perspectiva, interessa trazer à tona todo o processo de criação, de modo a acompanhar a fatura completa do projeto, dos primeiros esboços ao executivo e mesmo da obra construída. Daí porque o suporte ideal para análise deixa de ser os desenhos de publicação, em favor dos desenhos realizados no escritório para os mais diversos fins - desenvolvimento do projeto, apresentação das propostas aos clientes, aprovação na Prefeitura e acompanhamento da obra -, além de outras tipologias documentais que se referem à administração do escritório, à sua atuação em relação à clientela, aos diálogos e demandas por parte das construtoras e órgãos públicos responsáveis por seu acompanhamento e aprovação. 
Assim, ao se atentar, na pesquisa sobre Jacques Pilon, para problemas relativos ao processo de concepção e realização de uma obra em diálogo com o campo profissional, a cultura arquitetônica, as disposições técnico-materiais e o contexto urbano e social, um novo olhar foi lançado para o projeto de arquitetura, de modo a considerá-lo um documento/monumento, na acepção de Jacques Le Goff (LE GOFF, 1990). Simultaneamente, outros documentos que compõem o projeto de arquitetura e tratam do cotidiano da prática profissional foram assimilados pela análise como contratos sociais, memoriais descritivos, projetos complementares - fundação, estrutura, elétrica e hidráulica -, catálogos de materiais, cartas e ofícios trocados entre Pilon, seus clientes, colaboradores e técnicos da Prefeitura. Outros documentos também se mostraram necessários à análise, como fotos, revistas, jornais e entrevistas, visto que a divulgação e reflexão crítica sobre o trabalho fazem parte da atuação dos arquitetos e da constituição de seu campo disciplinar. ${ }^{6}$ Informações que a princípio passavam despercebidas no exame preliminar da documentação começaram a saltar aos olhos, indicando entradas de análise muito potentes, como, por exemplo carimbos, anotações realizadas às margens dos desenhos, etapas e organização na realização do projeto, relações entre desenhos de arquitetura e seus complementares, instrumentos de desenho, além da gama bastante diversa de fontes já citadas, pouco usuais à história da arquitetura. Todas elas, manejadas durante a pesquisa e cotejadas entre si, permitiram uma crítica apurada do contexto de elaboração, consumo e circulação dos documentos, contribuindo para a construção dos próprios problemas de investigação, indicando permanências e mudanças no campo arquitetônico e nas formas de produção social, material e plástica dos edifícios e da cidade.

A partir dessa perspectiva, interessaram como agentes tematizados pela pesquisa não só o arquiteto e seus colaboradores, mas também aqueles envolvidos anos depois durante a doação dos arquivos dos escritórios de Jacques Pilon e no estabelecimento de critérios de sua organização na Biblioteca da FAUUSP. É essa perspectiva alargada, bem como as indagações dela decorrentes, orientadas pela dialética entre fontes documentais e problemática histórica que é recuperada neste artigo, a partir de três focos: o primeiro, dirigido à constituição e organização do Acervo de Projetos da FAUUSP; outro, voltado para a Coleção Jacques Pilon; e, por último, alguns rendimentos que a análise do projeto de arquitetura a partir dessas questões permitiu.

acervo de projetos da FAUUSP: arquite(x)tura, temporalidade e trajetória

Ao contrário do que se possa pensar, nem sempre um arquivo é formado por intenções claras. Ele pode surgir de um conjunto de acontecimentos aparentemente fortuitos e desarticulados, externos à instituição onde foi criado. Contudo, a sua gratuidade incidental não isenta o pesquisador da necessária problematização do arquivo, entendido também ele como um constructo sócio-
6. Essa documentação foi consultada em diversas instituições: Biblioteca da FAUUSP; Arquivo Geral de Processos da Prefeitura Municipal de São Paulo; Arquivo Municipal Washington Luís; Centro de Estudos e Distribuição de Títulos e Documentos de São Paulo; Conselho Regional de Engenharia, Arquitetura e Agronomia de São Paulo, no Instituto de Arquitetos do Brasil, Junta Comercial do Estado de São Paulo e Tribunal de Justiça do Estado de São Paulo. 
7. Sobre essas diferenças e a produção historiográfica contemporânea, ver José Tavares Correia de Lira (2011), Joana Mello de Carvalho e Silva (2012), Marina Waisman (2013), Gustavo Rocha-Peixoto (2013), João Marcos Lopes e José Tavares Correia de Lira (2013).

8. Ainda que o Iphan já atuasse em São Paulo nos anos 1940 , contando com a participação de agentes próximos aos fundadores da FAUUSP, como Luís Saia, por exemplo, sua ação, ao contrário do que ocorrera no Rio de Janeiro, não se voltou para a produção contemporânea da cidade. Essa diferença mereceria ser investigada com mais vagar, algo que não é possível de se fazer neste artigo. histórico. Afinal, as suas condições de criação dizem sobre o período no qual foi instituído; sobre o campo profissional, políitico ou simbólico no qual se inseriv; sobre sua narrativa e constituição; sobre sua configuração, transmissão, organização, disponibilização e usos e sobre sua relação com a historiografia então vigente. Situação semelhante se revela no caso do Acervo de Projetos da FAUUSP, cuja criação e funcionamento têm vínculos estreitos com os planos de ensino e pesquisa traçados pela instituição desde a sua fundação.

A FAUUSP foi criada em 1948 como parte dos esforços de constituição de um campo arquitetônico independente, diverso daquele da engenharia em São Paulo (DURAND, 1974, 1989; FICHER, 2005; SILVA, 2012). Três seções técnicas de apoio faziam parte de seu plano pedagógico inicial: a Biblioteca, o Laboratório de Modelos e Ensaios, e o Laboratório de Publicação e Produção Gráfica, todos comprometidos com a tríade ensino, pesquisa e extensão. A ausência de uma seção destinada à guarda e conservação de projetos indica que, àquela altura, os mesmos não eram entendidos nem como instrumentos didáticos, nem como fontes de pesquisa histórica.

O ensino de projeto naquele tempo era pautado pela leitura de revistas especializadas, pelo diálogo com os docentes, pela experiência profissional em escritórios particulares ou em órgãos públicos e por visitas a edifícios já concluídos. A pesquisa histórica sobre a produção arquitetônica local, por sua vez, também se apoiava exclusivamente nas falas dos arquitetos, no exame dos edifícios recémconstruídos, na análise de fotos produzidas no momento de sua inauguração e na leitura de desenhos de publicação, em geral plantas, elevações, cortes e perspectivas simplificados para enfatizar a organização dos espaços e a linguagem do edifício. Apenas excepcionalmente eram publicados detalhes construtivos em revistas como a Acrópole, voltadas para o exercício profissional. Por sua produção, materialidade e abordagem, esses documentos reforçavam o ideal do gênio artístico, individual e isolado, pouco ou nada contando sobre o processo de concepção, materialização e apropriação da obra, dentro e fora do campo arquitetônico, questões que hoje orientam muitas pesquisas na área, mas que naquele momento não eram sequer formuladas. ${ }^{\text {? }}$

Essa ausência têm outras explicações. Ela se justifica também pelo fato de que os arquitetos envolvidos na criação da FAUUSP estavam na ativa, pensando a sua produção no âmbito da prática, como uma ação desenvolvida no presente, com olhos voltados para o futuro. Sua produção, pelo menos no âmbito do ensino, não era tomada como algo a ser preservado, porque se não the atribuía uma dimensão histórica. Se seus projetos eram guardados nos escritórios, isso se devia, sobretudo, por seu caráter operativo na conservação ou atualização por meio de reformas de suas obras (GUTIERREZ, 201 1), valendo como testemunhos preferenciais da trajetória dos arquitetos projetos realizados. ${ }^{8}$ De fato, no âmbito profissional era corrente a percepção de que a arquitetura só existia quando concretizada propostas irrealizadas, inconclusas ou intermediárias nem sempre recebiam o mesmo valor -, daí porque a preservação pública de desenhos não era propriamente um problema ou uma aspiração. 
Contribuiu para isso o desprezo que a maioria dos fundadores da faculdade nutria em relação à produção acadêmica pregressa, com a qual disputavam a constituição e o controle do campo arquitetônico em São Paulo, com impactos expressivos nas esferas de conservação, consagração e difusão (BOURDIEU, 1974a, 1974b, 1989a, 1989b). Nesse contexto, a produção que os antecedia não merecia ser preservada nem do ponto de vista material, nem documental.

Entretanto, com o passar dos anos, novas seções técnicas foram incorporadas à FAU, ${ }^{9}$ ao mesmo tempo que as existentes eram reformuladas em compasso com o alargamento dos contornos disciplinares da arquitetura e do urbanismo e, dentro disso, com mudanças nas orientações de ensino e pesquisa. No caso da Biblioteca, essa revisão consistiu na assimilação de outros fundos, para além do material impresso, adquiridos pela ação de agentes internos e externos, decorrentes de atividades didáticas ou doações que hoje compõem a Seção Técnica de Materiais Iconográficos.

Desse modo, a partir da década de 1960, novos documentos foram assimilados ao acervo, como fotografias, diapositivos, negativos de vidro, filmes, vídeos, microfilmes, seguidos de mapas e projetos de arquitetura e de urbanismo. Ao contrário da constituição dos acervos que englobaram os primeiros documentos, fruto da articulação entre Biblioteca e atividades didáticas em curso na FAUUSP, o de projetos foi criado de modo fortuito, a partir da doação do acervo do escritório de Carlos Millan (1927-1964), feita pela família, em 1965. Apesar da inexistência de um plano de constituição desse acervo, a doação foi aceita pela então diretora, Teresa Almásio Hamel, mesmo sem disponibilidade de espaço e de recursos para proceder à guarda, conservação e catalogação. Sua atitude teria se dado pelo reconhecimento da importância daquele gesto inicial dos herdeiros. ${ }^{10} \mathrm{O}$ acaso traz alguns significados importantes.

Em primeiro lugar, cabe destacar o propósito da família de perpetuar a memória do arquiteto e professor da faculdade. Articulado a isso, começava-se a perceber a Biblioteca como um lugar de memória, uma instância importante na constituição da história da arquitetura e do urbanismo. Analisando-se o conjunto de doações realizadas posteriormente (CATÁLOGO..., 1988; MARQUES, 2006), é patente o desejo recorrente entre familiares e profissionais de se tornarem parte da história, assim como o reconhecimento do papel da FAUUSP na definição daquilo que seria legado ao futuro da arquitetura e do urbanismo (DERRIDA, 1995). Nesse sentido, a doação comporta uma mudança de perspectiva, afinal, na década de 1960, alguns desses arquitetos começavam se desligar de suas atividades profissionais, deixando de representar o presente e o futuro da arquitetura, para entrar honrosamente na esfera do passado, como memória.

$\bigcirc$ fato de Carlos Millan, além de arquiteto, ser professor e, mais do que isso, um professor de projeto, carrega sentidos para essa doação que não devem ser ignorados. Afinal, seu acervo não documentava apenas sua trajetória individual, mas também a concepção de arquitetura que orientava o ensino de projeto na FAUUSP e era valorizada em livros e revistas comprometidos em definir os cânones
9. A FAUUSP conta hoje com cinco seções técnicas de apoio à docência, pesquisa e extensão: Seção Técnica de Modelos, Ensaios e Experimentações Construtivas; Seção Técnica de Audiovisual; Seção Técnica de Assistência e Divulgação Institucional; Seção Técnica de Informação e Produção de Bases Digitais; e Seção Técnica de Produção Editorial.

10. A informação sobre a participação da então diretora na doação foi fornecida durante entrevista com a bibliotecária responsável pela Seção Técnica de Materiais Iconográficos, Eliana de Azevedo Marques, no primeiro semestre de 2015. Vale lembrar que Millan era contemporâneo daqueles arquitetos, professor da instituição, e que faleceu prematuramente em um acidente de carro. 
da arquitetura moderna vigentes em São Paulo. Ele era, portanto, uma peça importante na constituição da esfera de consagração do campo arquitetônico na cidade, e isso pode ter pesado no aceite da doação por parte da Biblioteca.

A essa primeira doação, de 1965, seguiram-se outras. Considerando sua cronologia, nota-se que a grande maioria delas foi feita entre as décadas de 1980 e 1990. Tal concentração pode ser explicada por dois motivos: um deles, contingente, relativo ao desaparecimento de uma geração de arquitetos, o que se confirma pelo fato de que a maioria das doações foram feitas pelas famílias desses profissionais; o outro refere-se à revisão historiográfica que começou a tomar corpo justamente nesse período de consolidação dos programas de pós-graduação em arquitetura e urbanismo. Não é um mero acaso a presença, entre os doadores, de professores comprometidos com essa revisão, entre eles Carlos Lemos e Hugo Segawa. Nessa fase, três aspectos são centrais para sua caracterização: primeiro, a consideração do acervo do escritório como algo fundamental para a pesquisa; segundo, o interesse por diversos perfis e atuações profissionais; e, por fim, a valoração de manifestações arquitetônicas fora dos cânones modernos ensinados na faculdade e, de alguma forma, mesmo que não deliberadamente, afirmados no gesto inicial de criação do acervo.

Vale enfatizar que foi a ação desses professores e doadores particulares, aliada à recepção sem critérios claramente definidos por parte da Biblioteca, o que garantiu a diversidade de propostas e práticas arquitetônicas que hoje compõem a Seção Técnica de Materiais Iconográficos, o que the dá uma qualidade documental excepcional. Desse ponto de vista, a falta de um projeto curatorial mais claro foi positiva pela variedade de linhas arquitetônicas que a seção acabou contemplando, da produção de matriz acadêmica novecentista à gama de proposições modernas desenvolvidas do século XX à contemporaneidade, constituindo-se como uma possibilidade efetiva de uma escrita mais plural da história da arquitetura. Alguns arquitetos, entre eles Pilon, provavelmente teriam "desaparecido" da história, não fosse o acaso da acolhida de seu acervo pela FAU, bem como a ação de professores que encaminharam as doações e de outros pesquisadores que, na elaboração de novos problemas historiográficos, valorizaram outras linguagens e trajetórias. Colaborou para isso a maior independência, no âmbito da própria FAU, do campo da história da arquitetura em relação à prática profissional e, com isso, a elaboração de uma narrativa historiográfica menos operativa (LIRA, 2011 ).

A catalogação do acervo só começou a ser feita a partir da década de 1970, quando a faculdade já tinha se transferido da Vila Penteado, sua antiga sede no bairro de Higienópolis, para o campus do Butantã. A despeito dos esforços das bibliotecárias e da revisão historiográfica dos anos 1980 em diante, o ritmo da catalogação foi sempre muito lento, em parte pela desconexão entre o acervo e as atividades didáticas, em parte pelo desinteresse que a maioria dos pesquisadores nutria pela documentação ali guardada até muito recentemente. Ainda hoje, quase metade das cerca de setenta coleções não foi processada, 
mesmo com o empenho de bibliotecárias que vêm se aprimorando em técnicas de catalogação e de restauro. ${ }^{11}$ Existem, ademais, outros impasses.

As coleções foram organizadas a princípio por arquiteto/escritório, sendo compostas por um conjunto bastante variado de documentos, distribuídos pelas dependências da Biblioteca conforme a lógica de conservação, a disponibilidade espacial e as exigências de acondicionamento:

- tubos de projeto com desenhos à lápis ou à nanquim em papel-manteiga ou vegetal, ficam, quando já catalogados, na Sala de Atendimento da Seção Técnica de Materiais Iconográficos, na Sala de Originais "Eunice R. Ribeiro Costa" e na Sala Flávio Império. Quando não catalogados, tais materiais são acondicionados na Reserva Técnica;

- desenhos a lápis, aquarela, nanquim e grafite em papel-cartão, cambraia e afins estão guardados em mapotecas na Sala de Originais "Eunice R. Ribeiro Costa" e na Sala Flávio Império, à exceção do Caderno de Riscos Originais da FAUUSP, que se encontra na Sala de Obras Raras da Seção de Preservação;

- fotos, slides e negativos estão distribuídos entre a Sala de Obras Raras, a Sala de Atendimento da Seção Técnica de Materiais Iconográficos e em um espaço entre a área de consulta e a Seção Técnica de Materiais Bibliográficos;

- documentos paralelos - memoriais, cartas, ofícios, recibos, catálogos de materiais, notas fiscais, agendas etc. - em arquivos de papelão estão conservados na Sala de Atendimento da Seção Técnica de Materiais Iconográficos, na Sala de Originais "Eunice R. Ribeiro Costa" e na Reserva Técnica;

- revistas e livros nas estantes, distribuídos em meio ao acervo da Biblioteca.

A dispersão dos materiais nos espaços e bancos de dados da Biblioteca se configurou como um problema, pois subverteu a organização original do arquivo tal como ela se estabeleceu no escritório, rompendo a relação entre os documentos e o que ela podia informar sobre o arquiteto, sua prática profissional e projetual. $\bigcirc$ problema efetivamente ocorre porque as bases de consulta nem sempre indicaram que um dado documento pertencia a uma determinada coleção. Tal procedimento poderia facilmente sanar o problema da dispersão da coleção, permitindo a reconstituição de sua totalidade. É o caso, por exemplo, dos documentos paralelos, acima indicados, que têm interessado os pesquisadores em função das informações sobre a produção social da arquitetura e o exercício profissional. Ainda que questões práticas expliquem esses procedimentos, a sua implementação se deu pela prevalência do sistema de catalogação de bibliotecas em detrimento do adotado por arquivos, pelos limites orçamentários e espaciais do setor, mas também porque o que atualmente se mostra como uma questão e uma demanda, na década de 1970, ainda não se formulava. Por isso, também por parte da Seção Técnica de Materiais Iconográficos, novos esforços de organização e disponibilização das
11. A Seção Técnica de Preservação e Conservação de Materiais da Biblioteca da FAUUSP, do qual fazem parte Lisely S. C. Pinto, Maria Satiko Matsuoka, Rita de Cássia Camargo e Eunice Falqueiro, vem se aprimorando nas técnicas de conservação e restauro desse tipo de documentação. Vale apontar ainda que, na década de 1990, a Biblioteca empreendeu um projeto de pesquisa envolvendo alunos de graduação e visando à catalogação de sete coleções, entre elas as dos arquitetos Carlos Millan, Gregori Warchavchik e Elisiário Bahiana. Em 2010, as coleções de Jacques Pilon e Giancarlo Palanti foram parcialmente catalogadas durante o desenvolvimento das pesquisas do grupo temático São Paulo: os estrangeiros e a construção da cidade. Atualmente um esforço semelhante tem se realizado pela Seção Técnica de Materiais Iconográficos, sob a coordenação da bibliotecária Eliana de Azevedo Marques, com o acervo de David Libeskind (1929-2014), doado à Biblioteca em 2014 que ensejou o projeto do portal eletrônico Memória da Arquitetura Brasileira (MAB), em desenvolvimento com a coordenação técnica da bibliotecária Gisele Ferreira de Brito. 
12. Dewey e Cutter foram bibliotecários norte-americanos que desenvolveram o sistema de classificação que orienta a catalogação de livros ainda hoje. O primeiro desenvolveu a classificação decimal, enquanto o segundo procurou aprimorá-la para melhor identificação da autoria, introduzindo com isso, além de números, letras no sistema de classificação. No caso da classificação de projetos para assegurar a unidade da coleção, a Tabela Cutter é empregada antes do Sistema Decima de Dewey, de modo que a coleção fosse agrupada pela autoria e depois pelo programa da obra.

13. Tal comitê estabeleceu uma série de orientações específicas para acervos de desenhos técnicos e de arquitetura, descritas no Rules for Archival Description, disponíveis em <http:// www.cdncouncilarchives. ca/archdesrules.html>. Acesso em: 15 out. 2016. coleções têm sido realizados tanto no sentido de recuperar os nexos entre os diversos documentos doados, quanto no de dar aos pesquisadores o maior número possivel de informações, desde a doação até a sua guarda e conservação (SAKURAl et al., 2016).

O sistema de classificação adotado para esses documentos seguiu as orientações estabelecidas por Melville Louis Kossuth Dewey e Charles Ammi Cutter, ${ }^{12}$ empregadas para livros e periódicos, recentemente complementadas pelas orientações do Canadian Committee on Archival Description. ${ }^{13}$ Desse modo, cada projeto recebeu um número de tombo referente ao sobrenome do arquiteto e ao tipo de programa. A numeração das folhas seguiu inicialmente a lógica linear de desenvolvimento do projeto de arquitetura, da seção, ou seja, do estudo preliminar ao executivo, das plantas de arquitetura aos complementares, da implantação aos detalhes, passando pelas plantas, cortes, fachadas e perspectivas, sempre que possível seguindo a cronologia de datação dos desenhos. Atualmente, em função do aumento significativo do número de coleções, da intenção de disponibilizá-las ao público com celeridade, da diminuição do quadro funcional da seção e da utilização de bancos de dados mais eficientes, a numeração segue a organização original dos tubos de doação por projeto, o que nem sempre está de acordo com a sequência antes indicada.

Se o sistema de numeração das follhas parece perfeitamente adequado para a tipologia, o mesmo não se pode afirmar com relação ao sistema de catalogação. Nele, além dos problemas acima apontados, informações centrais na descrição - por exemplo, tipo, dimensão e meio do desenho, nome do cliente, estágio do projeto etc. - nem sempre são informadas, motivo pelo qual a Seção Técnica de Materiais Iconográficos vem procedendo a um conjunto de revisões no sistema de catalogação e consulta.

Há, portanto, esforços sensíveis, desde os anos 1980, para ampliação da catalogação, conservação e extroversão das coleções. Uma ação pioneira foi realizada em 1988 com o lançamento do Catálogo de desenhos de arquitetura da FAUUSP, realizado com financiamento da Fundação Vitae - Apoio à Cultura, Educação e Promoção Social, e disponibilizado, em 2005, por meio do site da Biblioteca (CATÁlOGO..., 1988; ULIANA, 2013). Em 2010, parte da coleção Jacques Pilon e Giancarlo Palanti foi digitalizada e disponibilizada no site São Paulo, os estrangeiros e a construção da cidade, como resultado das pesquisas do projeto temático Fapesp de mesmo nome (SÃO PAULO..., [s.d.]).

Vale atentar para o fato de que o movimento de doação voltou a aumentar nos últimos anos. Tal incremento coloca novos desafios para a Seção Técnica de Materiais Iconográficos, submetida ainda às contingências orçamentárias e espaciais. Seria preciso definir um plano mais preciso do ponto de vista didático e historiográfico, desde a doação até divulgação do acervo, aliado, é claro, aos enfrentamentos necessários à revisão de alguns critérios de catalogação, com a reformulação ou complementação dos bancos de dados; à constituição de espaços adequados para conservação, restauro e consulta, sem perder de vista a qualidade 
original do acervo: a sua diversidade. É exatamente nesse sentido que têm se encaminhado os esforços e revisões da referida seção. As especificidades, condições e limites da guarda, organização e disponibilização dos documentos que compõem o Acervo de Projetos revelam as concepções de ensino e pesquisa então vigentes, indicando que, em função de sua contínua revisão, deve haver espaço para mudanças que permitam a introdução de novos campos de consulta nas bases, novas relações entre os diferentes tipos de documentos e novas fontes de investigação, que possam ser continuamente assimiladas, como tem sido testado com a Coleção David Libeskind.

$\bigcirc$ crescente interesse pelo Acervo de Projetos e os problemas aqui apontados se vinculam ao aprofundamento da revisão historiográfica iniciada na década de 1980 e, dentro dela, ao alargamento dos sentidos da arquitetura, como profissão e objeto de pesquisa. Nesse contexto, como se procurou mostrar, passou a interessar aos pesquisadores não só a obra construída e o discurso do arquiteto, mas também a dimensão coletiva e temporal da arquitetura; a sua produção; as interferências externas de outros técnicos - engenheiros responsáveis pelos projetos complementares, técnicos da Prefeitura, etc. - e dos clientes; as formas de uso e de apropriação dos edifícios pelos usuários; os problemas e desafios enfrentados na sua preservação e adaptação ao longo do tempo. Como bem apontou Josep Maria Montaner (2014, p. 35), a arquitetura "nunca é estática, nunca é um objeto que ficou congelado no momento em que se inaugura", por isso "temos que levar em conta [...] o que aconteceu, o que tinha antes, afinal nenhuma obra, nenhum processo humano é casualidade, é sempre o resultado de um campo de forças, de lutas urbanas". Tais disputas, como se viu, estão presentes também na constituição dos acervos e de suas coleções.

A Coleção Jacques Pilon: a dialética entre problemas e fontes historiográficas

Além da dimensão material e discursiva da Seção Técnica de Materiais Iconográficos da Biblioteca, uma outra, voltada à análise da Coleção Jacques Pilon em suas relações com a constituição do campo arquitetônico, merece ser investigada.

A doação e organização inicial da referida coleção foi realizada, em 1988, pela pesquisadora llda Helena Diniz Castello Branco, na época envolvida com a pesquisa Arquitetura no centro da cidade edifícios de uso coletivo, São Paulo: 1930-1950 (BRANCO, 1988; WARCHAVCHIK, 1983), a quem a família do arquiteto francês confiou o material completo de seus escritórios. Intermediando o processo, aparece o arquiteto e professor da FAUUSP, Gian Carlo Gasperini (1926-), figura central para compreender as motivações da doação, seus usos políticos e simbólicos. Tais aspectos só puderam ser notados e avaliados no embate com a documentação e seu cruzamento com os três problemas centrais de minha tese de doutorado acima explicitados. 
Gasperini foi um dos muitos arquitetos estrangeiros a se radicar no Brasil entre os anos 1930 e 1950. Estabelecido inicialmente no Rio de Janeiro, o arquiteto se transferiu para São Paulo a convite de Jacques Pilon para assumir, em 1951, o cargo de chefe de seu escritório, no lugar do alemão Franz Heep (19021978). A mudança foi fundamental para a carreira do italiano que, anos mais tarde, em 1962, constituiu um escritório em sociedade com Plínio Croce (19211984) e Roberto Aflalo (1926-1992), em alguma medida responsável por dar continuidade ao legado de Pilon na cidade e, sem dúvida, uma referência importante para o mercado imobiliário paulistano. Desse ponto de vista, a doação foi motivada não só pela gratidão e admiração que Gasperini nutria por Pilon, mas também por sua intenção de legar à história a sua própria contribuição e, com isso, abrir espaço para uma produção que, por seus vínculos com o setor imobiliário, não encontrava tanta acolhida entre os professores de projeto e os historiadores da arquitetura na FAUUSP naquele momento. Vale apontar que essa resistência tem a ver com o processo de constituição do campo arquitetônico no Brasil.

Durante a consolidação desse campo, além da diferenciação das atribuições dos arquitetos em relação aos práticos e engenheiros, outra distinção profissional foi se constituindo no confronto com o processo de metropolização em curso, sobretudo, a partir dos anos 1950, e de radicalização das posições políticas no horizonte da Guerra Fria. Nesse contexto, o vínculo com o mercado imobiliário que orientava a prática profissional desde a virada do século XIX para o XX começou a ser criticado a partir de uma nova visão da arquitetura, tanto em termos disciplinares quanto políticos. Assim, do ponto de vista de um grupo de arquitetos, era preciso superar o caráter excessivamente elitista da profissão, rompendo com o seu isolamento e promovendo a sua democratização de modo a "atender às necessidades imediatas de milhões de brasileiros que hoje sofrem da falta de habitações condignas, de escolas, hospitais, estádios e locais para a cultura espiritual e física" (RIBEIRO; SOUZA; RIBEIRO, 2003, p. 206). A arquitetura, portanto, não deveria estar a serviço das elites, ao contrário, ela deveria se comprometer politicamente com a construção da nação, contribuindo para o seu desenvolvimento social (DURAND, 1974, 1989; JULIANI, 2002, p. 143-161).

Esse compromisso marca o discurso que Oscar Niemeyer (1907-2012) fez sobre sua atuação em textos como O problema social na arquitetura, de 1955, e Depoimento, de 1958. A autocrítica empreendida pelo arquiteto carioca especialmente no último artigo foi louvada por João Batista Vilanova Artigas (19151985), porque representaria, do seu ponto de vista, o abandono dos "aspectos de submissão ao imobiliário, que [a arquitetura brasileira vinha exibindo], para se projetar com pureza no plano da manifestação cultural, única forma de ser compreendida". Figura central na estruturação do Departamento de Projeto da FAUUSP e da própria faculdade, Artigas acreditava naquele momento que a participação dos arquitetos no mercado imobiliário não só era condenável por submeter o "projeto à força do capital na produção do espaço", como imoral por comprometer suas propostas em funções de decisões orientadas para a obtenção 
de um maior lucro. Nesse sentido, defendia veementemente a separação completa das atividades de criação e de execução da obra, única forma de coibir "qualquer associação do técnico e do artista a interesses comerciais decorrentes de seus projetos" (ARTIGAS, 2003, p. 240). Por isso, os arquitetos deveriam deixar de exercer a atividade simultânea de construtor para se concentrarem naquela atividade que, a partir desse momento, passava a definir a especificidade de sua atuação profissional, o projeto.

Essa separação constitui em São Paulo um campo arquitetônico independente, justamente a partir dos anos 1950. Tal consolidação - como ocorre em outros campos profissionais na percepção de Bourdieu para a experiência francesa - dá aos arquitetos

a possibilidade de em suas práticas e nas representações que possuem de sua prática afirmar, ao mesmo tempo - por via de um aparente paradoxo -, a irredutibilidade da obra de arte ao estatuto de simples mercadoria, e também, a singularidade da condição intelectual e artística. (BOURDIEU, 1974a, p. 103)

No campo da literatura e das artes, essa afirmação partiu de um grupo que, imbuído de um ideário de liberdade criadora, procurou diferenciar a sua produção das demandas do mercado, tanto popular quanto burguês, e produzir para um "receptor ideal que se traduz em um alter ego, ou melhor, outro 'criador', contemporâneo ou futuro, capaz de mobilizar em sua compreensão das obras a disposição 'criadora' que define o escritor e o artista autônomos" (BOURDIEU, 1974a, p. 103-104). Podemos nos apropriar dessa leitura para pensar o campo arquitetônico, lembrando que essa diferenciação se constituiu por meio de esferas de conservação, consagração e difusão locais, tais como o Instituto de Arquitetos do Brasil, o Museu de Arte Moderna (MAM), o Museu de Arte de São Paulo (Masp), a Bienal de Arte e de Arquitetura, a revista Acrópole, entre outros periódicos, todas criadas entre o fim da década de 1930 e o início da de 1950.

No Brasil, a distinção hierárquica entre a produção erudita e a indústria cultural se deu em meio a um processo de politização que atingiu todos os campos da cultura. No caso da arquitetura, ela levou à definição de dois tipos de arquitetos: o arquiteto de mercado, dono de empresas vinculadas à atividade construtora e imobiliária, que seria guiado apenas por interesses comerciais; e o arquiteto independente, profissional liberal, em geral dono de um pequeno escritório, sempre que possível dedicado a encomendas públicas de alcance social. Enquanto o primeiro foi sempre menos valorado entre aqueles que dominaram o campo profissional, o segundo se tornou o ideal a ser atingido por todos aqueles que optavam pela disciplina.

A inserção de um acervo de projetos identificado com o mercado imobiliário na Biblioteca da FAUUSP, instituição que era vinculada à defesa do perfil autônomo e social do arquiteto, colaborou ativamente nessas disputas pelo campo, sendo uma aposta de Gasperini de que ela poderia impactar tanto o ensino de projeto como a narrativa sobre o passado da arquitetura em São Paulo. 
Tal aposta obteve sucesso, ao menos no âmbito historiográfico, mesmo que para isso tenham se passado mais de vinte anos entre a doação, a catalogação, avaliação e divulgação da contribuição de Pilon e seus colaboradores - entre eles Herbert Duschenes (1914-2003), Franz Heep, Gasperini e Jerônimo Bonilha (1933) - à cidade e sua arquitetura (BARBOSA, 2002, 2012; FRANCO, 2009). Assim, sua presença no acervo da FAUUSP possibilitou novas narrativas, ao mesmo tempo que elas só se constituíram a partir de novas abordagens teórico-metodológicas e, com isso, a formulação de novas perguntas que exigiram, num movimento circular, novos documentos. Cumpre, agora, mostrar os rendimentos que esse movimento permitiu na análise da documentação.

Projeto arquitetônico

\section{Campo, representação e memória}

Durante a análise seriada dos projetos realizados por Pilon, primeiro em parceria com o engenheiro brasileiro Francisco Matarazzo Neto (1910-1980), depois individualmente, chamou atenção a diversidade de carimbos apostos aos desenhos. Em cada um deles, o arquiteto francês se apresentava de um modo específico, revelando estratégias de inserção social e profissional diversas referentes à sua condição de estrangeiro e às disputas pelo campo disciplinar em São Paulo.

Ao tratar da constituição de grupos étnicos, o antropólogo Fredrik Barth afirma que os subterfúgios de inclusão "dos de fora" oscilam entre a tentativa de se fazer passar por membro do grupo de destino, incorporando-se a ele, de acomodação ao estatuto de "minoria" e de escolha do "realce da identidade étnica" ou "estrangeira". Ele aponta também que um mesmo indivíduo pode valerse de todas as estratégicas acima indicadas, a depender do momento e da situação enfrentada (BARTH, 1997, p. 185-227). Ora, era justamente isso que os carimbos revelavam. Afinal, a diversidade de autoatribuições (Figura 1) correspondia à variação do tipo e da finalidade do desenho; às mudanças na legislação de imigração; e às transformações pelas quais a profissão passou no período.

Durante os anos da Pilon \& Matarazzao Ltda (Pilmat), entre 1934 e meados de 1940, os carimbos estampavam as qualificações correntes de engenheiro, arquiteto e construtor. Tais denominações correspondiam às formas de atuação de muitas firmas do período que atuavam simultaneamente como escritórios e construtoras, podendo agir também na administração e comercialização de imóveis, como é possível acompanhar na seção "Indicador Profissional" da revista Acrópole. Os investimentos imobiliários estavam entre os mais comuns e rentáveis na cidade e a associação entre engenheiros, arquitetos e construtores estava presente não só na prática profissional e empresarial como no âmbito institucional, como fica claro no decreto que regulamentava as profissões de engenheiro, arquiteto e agrônomo. 


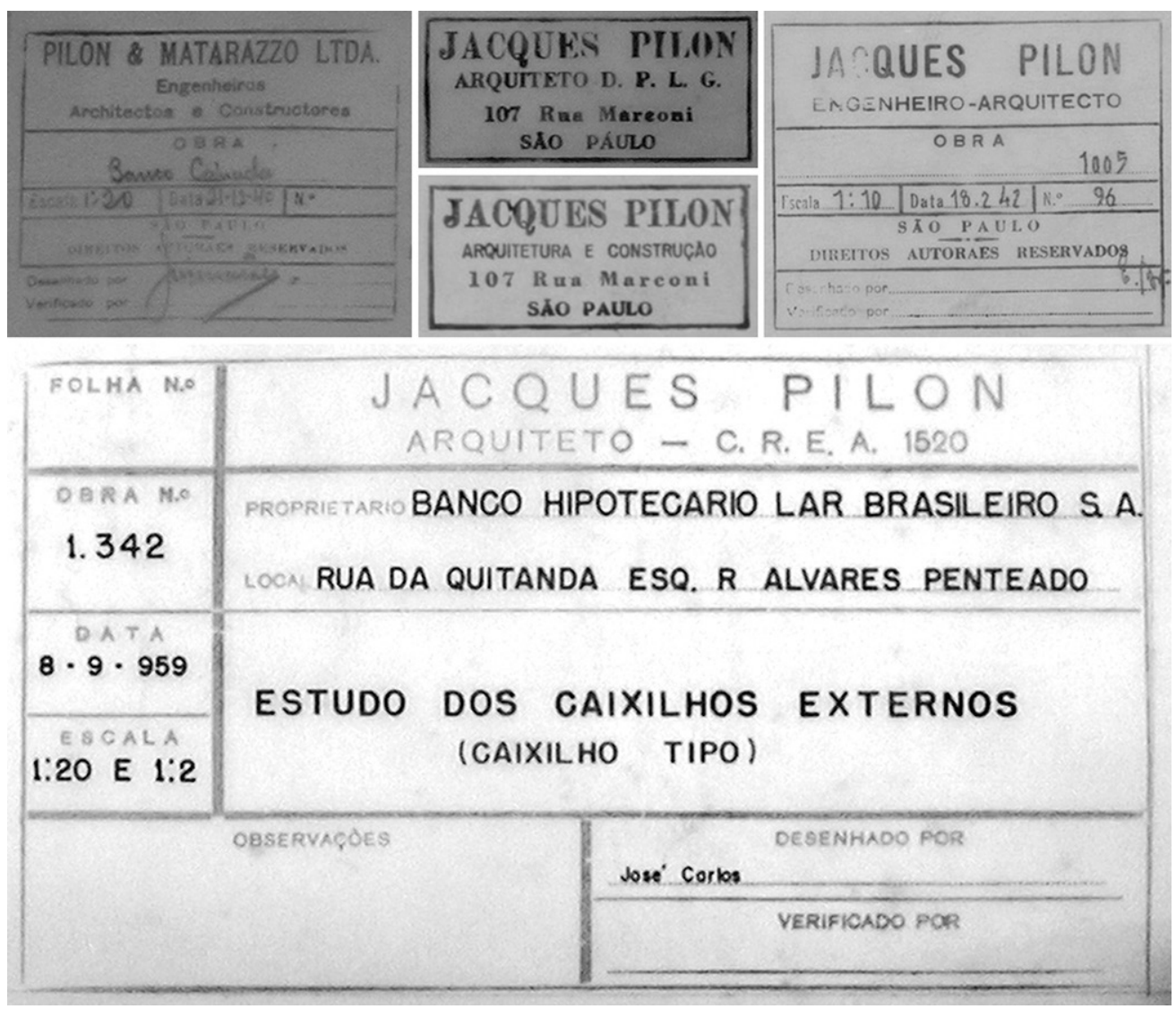

Figura 1: Carimbos dos escritórios de Jacques Pilon, em plantas de 1934 a 1955. Fonte: Coleção Jacques Pilon do acervo de projetos da Biblioteca da FAUUSP, São Paulo.

Promulgado em 1933, o Decreto-Lei n. 23.569 estabelecia que, das sete atribuições pertinentes ao exercício das profissões de engenheiro, de arquiteto e de agrimensor, apenas três, relativas às obras de caráter artístico ou monumental, de paisagismo ou decoração, eram exclusivas aos arquitetos. Todas as outras, referentes ao estudo, projeto, direção, fiscalização e construção de edifícios e projetos complementares, além de serviços de urbanismo, de arquitetura legal e de perícia, cabiam também aos engenheiros civis. Tanto a comunhão quanto as diferenças entre as atribuições de arquitetos e engenheiros são reveladoras das disputas pelo campo disciplinar e das acomodações empreendidas para a aprovação do decreto. Isso porque, à época, o objetivo considerado mais importante não era a distinção entre engenheiros e arquitetos, mas a limitação da ação de mestres de obras, artesãos e construtores práticos.

De fato, à exceção de Minas Gerais, as primeiras faculdades autônomas de arquitetura só foram criadas a partir de meados de 1940, por isso não era possível estabelecer na década de 1930 uma distinção legal entre arquitetos e 
engenheiros (FICHER, 2005; PEREIRA, 2005; LEMOS, 2010). Assim, menos do que confirmar o "prestígio" dos engenheiros, a "posição subalterna" dos arquitetos ou a manutenção de certa conotação "pejorativa" à disciplina, como afirma a bibliografia (DURAND, 1974; WEIMER, 2004, 2006; FICHER, 2005), o decreto de 1933 condensava as disputas pelo campo entre diplomados e não diplomados (PARETO JÚNIOR, 2016). O decreto aponta também disputas entre aqueles que concebiam a arquitetura como uma atividade eminentemente artística, como Christiano Stockler das Neves (1889-1982), e aqueles reunidos no Instituto de Engenharia e na Sociedade de Arquitetos e Engenheiros que consideravam a arquitetura como uma especialidade da engenharia, projeto e obra sendo pensados como atividades pertinentes a um mesmo profissional (PEREIRA, 2005). Foi justamente essa última concepção que se impôs, em grande medida, naquele momento, embora algumas sutilezas mereçam destaque.

Pilon se utiliza simultaneamente de três tipos de inscrições no carimbo de seu escritório individual até os anos 1950, momento de consolidação do campo arquitetônico: "Jacques Pilon engenheiro-arquiteto"; "Jacques Pilon arquitetura e construção" e "Jacques Pilon Arquiteto D.P.L.G". A presença dos termos engenharia, arquitetura e construção remonta à prática profissional vigente no período, mas a sua utilização em carimbos separados comprova as suas estratégicas de inserção profissional, daí a importância de se atentar para o tipo, a finalidade e o destinatário do desenho.

A qualificação engenheiro-arquiteto era utilizada preferencialmente nos desenhos apresentados à Prefeitura como meio de qualificá-lo a partir dos atributos que à época alcançavam maior valoração entre os profissionais da área. A qualificação engenheiro garantia certo status, além de afirmar as capacidades necessárias àqueles que se dedicavam ao projeto e à obra naquele período. Os termos arquitetura e construção constavam nos carimbos impressos nos desenhos que seguiam para a obra, indicando a dupla atividade entre a prancheta e 0 canteiro. $O$ atributo Arquiteto D. P. L. G, por sua vez, era gravado nos desenhos de apresentação do projeto ao cliente. A sigla D. P. L. G-Architecte Diplômé par le Gouvernement - indicava que Pilon tinha se formado na Escola de Belas-Artes de Paris, naquele momento ainda a mais prestigiosa instituição de ensino no Ocidente, inclusive entre os clientes locais, fascinados pela possibilidade de acessar no Brasil a produção acadêmica francesa que tanto admiravam em suas viagens a Paris.

A simultaneidade de atribuições perdurou até meados do século XX. De fato, mesmo que a partir da década de 1930 o Estado tenha investido na regulamentação profissional e na expansão do ensino de nível superior - e que os próprios profissionais tenham buscado definir ou rever a sua atividade em contraponto a outras áreas do saber, formando para isso entidades de classe, organizações culturais e periódicos -, a especialização do trabalho artístico, técnico e científico só se consolidou no Brasil nos anos 1950 (PASSOS, 1992). Foi apenas nesse momento, quando a autonomia do campo profissional se 
estabeleceu, que essa variação foi se arrefecendo com a afirmação de um único carimbo, no qual Pilon se apresentava somente como Arquiteto.

Os subterfúgios utilizados pelo arquiteto francês só puderam ser notados pela disponibilidade das séries documentais sob a guarda da Biblioteca da FAUUSP, mas também porque o seu processamento se deu norteado pelas questões de pesquisa que os documentos, por sua vez, ajudaram a formular.

\section{Campo, prática profissional e concepção arquitetônica}

Ao longo do processo de realização do projeto, dos primeiros croquis ao projeto executivo, passando pelas plantas de aprovação na Prefeitura, memoriais descritivos, projetos complementares, anotações e revisões, os carimbos revelaram também outros dados interessantes sobre a prática profissional e as concepções arquitetônicas vigentes entre os anos 1930 e 1960.

Localizados à margem direita inferior do desenho, os carimbos trazem dados sobre o nome do escritório; o título da obra; a escala do desenho; a data de sua realização; o número da folha; e quem desenhou e verificou a proposta apresentada. Essas informações são cruciais no desenvolvimento do projeto e acompanhamento da obra, atividades que envolvem várias pessoas, em locais e momentos diversos e que, por isso, devem orientar os profissionais acerca das etapas e revisões de projeto, da finalidade e ordenamento dos desenhos e seus responsáveis. Sem eles, ainda mais em um contexto de produção simultânea de diversas obras, torna-se muito difícil saber a quais pessoas se devem determinados desenhos e se estes são a solução definitiva ou não para o desenvolvimento da arquitetura e dos projetos complementares, bem como para a execução da obra.

A configuração e as transformações dos carimbos ao longo do tempo, portanto, ajudaram a recompor a organização dos escritórios de Pilon, os papéis desempenhados por seus membros e colaboradores e as interferências externas de clientes ou técnicos da Prefeitura. Eles permitiram concluir, por exemplo, que a organização da Pilmat e do escritório individual de Pilon seguia a lógica apreendida nos ateliês da Escola de Belas-Artes de Paris. Ainda que o objetivo final dos exercícios daquela escola fosse o desenho do edifício e não a sua construção propriamente dita, nota-se que as etapas de desenvolvimento de projeto ali aprendidas se adaptaram ao exercício profissional. Sua divisão seguia o mesmo esquema do ateliê de projeto: concepção ou estudo preliminar, desenvolvimento ou anteprojeto e detalhamento ou projeto executivo, cumpridas pelos mesmos agentes: patron ou dono da empresa, veteranos ou chefes do escritório, novatos ou desenhistas (CHAFEE, 1977). Essa sequência pode ser acompanhada no projeto do Edifício Ernesto Ramos, cujo estudo preliminar, assinado por Pilon, foi desenvolvido por um desenhista identificado como GD, ou do Edifício São Luís (1940-1942), também concebido pelo arquiteto francês, desenhado por $\mathrm{HD}^{14} \mathrm{e}$
14. É possível que a sigla HD se refira ao arquiteto alemão Herbert Duschenes (1914-2003), que trabalhou no escritório de Pilon na primeira metade dos anos 1940 . 
verificado por outro arquiteto que anulou uma das soluções intermediárias, marcando ao lado esquerdo da folha "nulo".

$\bigcirc$ projeto de arquitetura em escritórios como os de Pilon, portanto, é resultado de etapas definidas, executadas em separado, mas de modo coordenado, entre autores, coordenadores e desenhistas, responsáveis por sua concepção, direção e detalhamento, numa organização sequencial e hierárquica, que possibilitava a realização simultânea de até dezenove projetos. Assim, ao contrário do pequeno ateliê de arquitetura, cujo proprietário realiza todas as etapas, desde atividades criativas até as funções administrativas, nos escritórios de Pilon cada momento do desenho e seu detalhamento era realizado por um profissional ou um conjunto de profissionais específicos. Nessa estrutura, o arquiteto francês foi cada vez mais assumindo o papel de administrador, coordenando as atividades de vários profissionais em cada uma das etapas de seu desenvolvimento. Se no pequeno ateliê o projeto é a afirmação do trabalho autoral, nos escritórios do porte e do tipo de organização alçada por Pilon, ele é pensado como um produto da empresa, por isso os nomes dos chefes de escritórios, responsáveis muitas vezes pela criação projetual, assim como os dos demais envolvidos, nem sempre eram divulgados, sendo que raramente apareciam nos periódicos da época.

É curioso notar que a forma de ordenação dos escritórios de Pilon, aprendida dentro da Escola de Belas-Artes de Paris, no seio de uma tradição acadêmica que valorizava a autoria e o pequeno ateliê, foi perfeitamente adaptada "ao perfil do 'grande escritório' norte-americano; este, entendido como uma empresa de arquitetura intrinsecamente vinculada a empreendimentos em grande escala, em que fatores como ritmo de produção e economia de custos são fundamentais" (NOBRE, 2008, p. 156). Essa adaptação só foi processada por Pilon no Brasil, uma vez que em Paris ele praticamente não atuou como arquiteto, dada que sua mudança para o país ocorreu logo depois de sua formatura. Foi, portanto, no exercício profissional, frente às exigências relativas aos prazos e aos custos de execução da obra, ausentes no ensino da arquitetura, que ele concebeu a referida organização, cuja inspiração no método de organização de trabalho taylorista e nos sistemas de produção e gestão fordista se faz notar, seja na especialização das atividades entre autor, coordenador e desenhistas, seja na introdução paulatina e continuamente aprimorada de técnicas, instrumentos, padronização e controle do projeto.

Inserido em uma cadeia produtiva mais ampla, o projeto de arquitetura se reorganizou a partir de meados dos anos 1950 para atender, de modo mais eficiente, tanto à sua realização no escritório quanto à sua construção no canteiro de obras. Não é por acaso que os dados constantes nos carimbos do escritório foram reorganizados e outros foram assimilados, como título do desenho - planta, corte, elevação, detalhe, perspectiva - e descrição de todas as modificações realizadas na folha, de modo a tornar mais eficiente a sua leitura. Além disso, as folhas de desenho, até então variáveis no tamanho e tipo de papel, começaram a ser padronizadas, todas com o mesmo tamanho, conforme o estágio de 
desenvolvimento de projeto. Ao mesmo tempo, os desenhos, inicialmente feitos em grafite com letras escritas a mão, passaram a ser realizados em nanquim, com instrumentos como normógrafo, gabaritos e Letraset, com o mesmo propósito de precisão. No mesmo sentido, as folhas de desenho começaram a ser organizadas do geral para o particular, conforme as etapas de construção: implantação, plantas, cortes, elevações e detalhes, conforme o executante (marceneiro, serralheiro etc.) e os elementos construtivos (portas, janelas, forros, pisos, móveis etc.), seguidos dos projetos complementares de fundações, estrutura, hidráulica e elétrica.

O aprofundamento da padronização do desenho e o maior detalhamento do projeto são resultados da maior especialização no campo arquitetônico, cuja característica marcante, como se viu, foi a maior separação entre projeto e obra. De fato, de 1930 até o final de 1940, os projetos desenvolvidos pelos escritórios de Pilon não ultrapassavam a fase de aprovação na Prefeitura, atingindo no máximo o que hoje se define como anteprojeto, ou seja, um estágio intermediário, no qual as linhas gerais do edifício estão lançadas, sem o detalhamento de sua execução. Essa prática se justifica porque a maioria dos escritórios de arquitetura consistia simultaneamente em empresas construtoras, por isso a equipe que realizava o projeto acompanhava cotidianamente a sua execução, deixando para o canteiro de obras parte das soluções construtivas definitivas. Tal atitude se apoiava também no fato de que no canteiro de obras havia artesãos - serralheiros, gesseiros, telhadistas, entre outros -, donos de uma experiência e um conhecimento com os quais os arquitetos e engenheiros podiam contar. Por isso, bastavam desenhos preliminares para que a obra começasse, deixando o detalhamento para a mão de obra especializada.

A fase do projeto, portanto, "não findava na sua apresentação ao cliente e aprovação pelos órgãos competentes, mas retornava, de forma dinâmica, até se encontrar a melhor proposta" (ROSSETTO, 2002, p. 105), tendo em vista as exigências da legislação, os interesses dos investidores, as mudanças do mercado imobiliário, além da dinâmica própria dos canteiros de obras. Tanto na Coleção Jacques Pilon da Biblioteca da FAUUSP quanto no Arquivo Geral de Processos da Prefeitura Municipal de São Paulo foram encontrados vários projetos modificativos apresentados durante e após a conclusão do projeto que confirmam essa análise. Havia desde modificações no arranjo dos espaços internos em função da execução da estrutura de concreto armado de modo diverso ao do projeto, como ocorreu no Edifício Paissandu (1935-1936), até alterações de uso, como nos casos dos edifícios comercial Edlu (1943-1947) e residencial Atlanta (19451949), originalmente destinados aos usos residencial e comercial, respectivamente. Havia também mudanças de gabarito, como a que se fez no Edifício-Sede dos Diários Associados (1943-1947), construído com três pavimentos a mais do que o projeto aprovado inicialmente pelos órgãos municipais.

A consolidação do campo arquitetônico em meados dos anos 1950 alterou também essa dinâmica. Nesse processo, a especialização das atividades de arquitetos e engenheiros impingiu um distanciamento dos primeiros com relação 
ao canteiro de obras. Na disputa pelo campo, os arquitetos afirmaram o caráter intelectual de sua atividade profissional, valorizando o projeto como seu produto final, relegando aos engenheiros a prática construtiva. Tal dissociação alterou o antigo diálogo entre prancheta e canteiro, estabelecendo-o em outros termos, não mais de modo direto, por meio do diálogo entre os diversos profissionais da área, mas de modo indireto, intermediado pelo maior detalhamento do projeto. Nesse processo, os desenhos deveriam falar por si, deixando de se configurar como um guia geral para um saber fazer consolidado, dominado por outros agentes no canteiro de obras, para se afirmarem como um manual de como fazer, conforme as diretrizes do arquiteto. Como consequência disso, os artesãos foram paulatinamente perdendo espaço, tendo sua prática sido tolhida por meio da legislação profissional que foi se estabelecendo a partir dos anos 1920. Em seu lugar, foi se assentando uma mão de obra cujo conhecimento era muito diverso, com o qual não era possível contar sem a definição prévia da solução no escritório de arquitetura (GITAHY; XAVIER, 2002; PARETO JÚNIOR, 2016$).$

Mas a dinâmica entre projeto e obra não se alterou apenas em função das transformações da prática profissional entre arquitetos, engenheiros e construtores em geral. Contribuiu para tal mudança a maneira pela qual os arquitetos pensavam a disciplina. Entre os anos 1930 e 1940, apesar da diversidade de linguagens adotadas, predominava na produção de Pilon a concepção da arquitetura como uma obra de arte regida por princípios de composição, simetria, ordem e harmonia. Nessa perspectiva, as questões técnicoconstrutivas não eram matéria de expressão poética, nem mesmo um campo de reflexão dos arquitetos, cabendo aos engenheiros e artesãos a sua definição. Daí porque os desenhos eram pouco detalhados, permanecendo no nível de um anteprojeto. A partir dos anos 1950, contudo, a despeito do distanciamento do canteiro de obras, os arquitetos tomaram os elementos constitutivos do edifício, sua execução e seu funcionamento, como definidores da arquitetura, deslocando - foco da linguagem para a construção. Assim, empenhar-se em encontrar soluções técnicas compatíveis com exigências materiais e financeiras e esteticamente bem resolvidas, em termos de linguagem, execução e funcionamento, passou a ser uma preocupação para os arquitetos e uma atribuição profissional específica por eles reivindicada em função das mudanças nos parâmetros que orientavam o projeto, além das transformações ocorridas no âmbito da prática. Entre os vários exemplos verificados ao longo da pesquisa, os projetos das janelas dos edifícios comerciais Ernesto Ramos (1940-1942) e Vicente Filizola (1943-1952), realizados sob a coordenação de Pilon e Heep, respectivamente (Figuras 2 e 3), parecem especialmente instrutivos a respeito das transformações em curso na prática projetual dos arquitetos do período.

Apesar da depuração ornamental rumo a uma linguagem geométrica próxima das vanguardas via art déco, nota-se que a composição da fachada do edifício Ernesto Ramos se orienta pelos parâmetros acadêmicos (CHAFEE, 1977), 


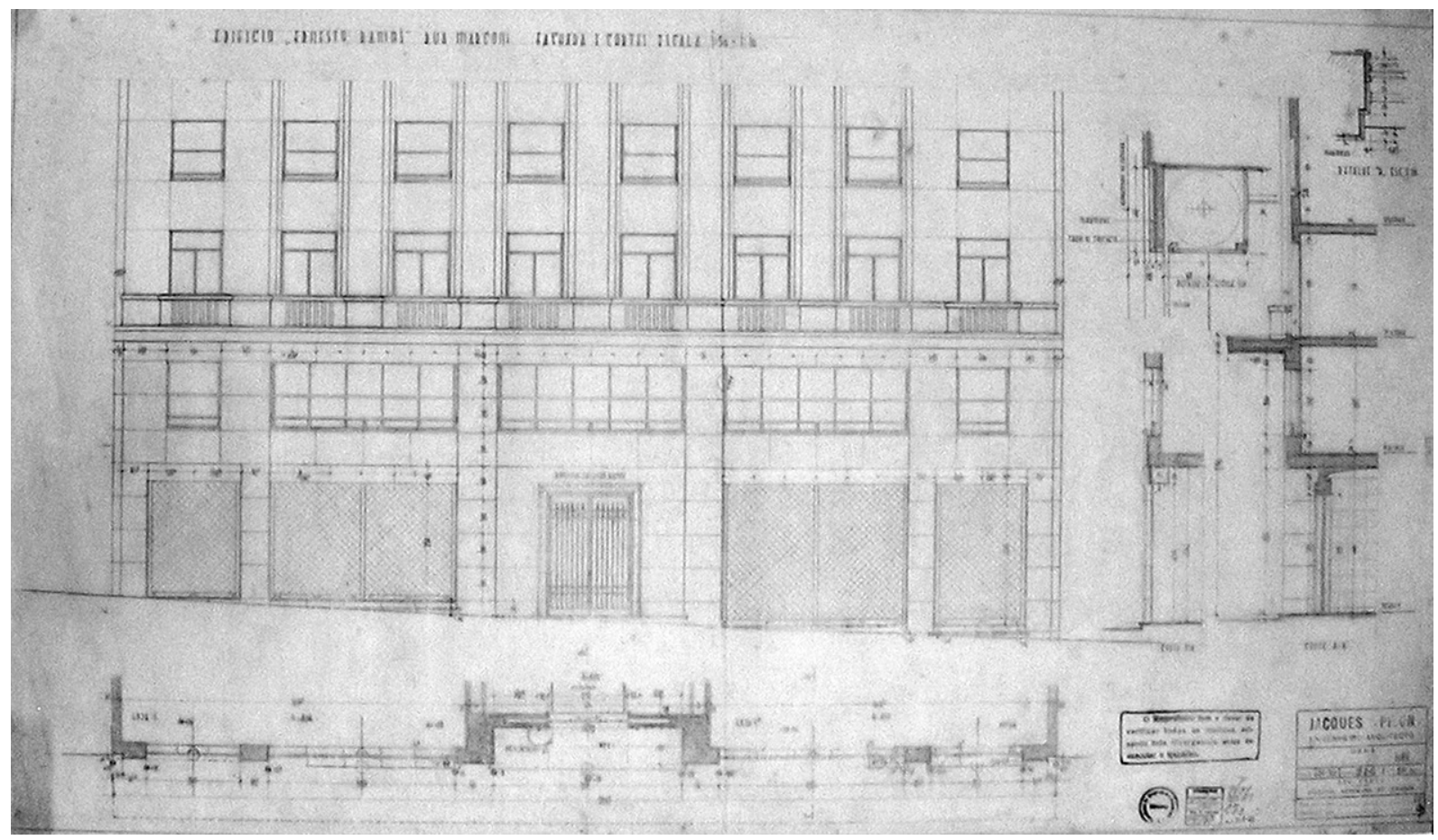

Figura 2: Edifício Ernesto Ramos, rua Marconi, São Paulo. Estudo da fachada principal. Fonte: Acervo da Biblioteca da FAUUSP, São Paulo.

com a distribuição das janelas acompanhando a ordem simétrica e tripartida da fachada. Seu desenho se restringe à definição das dimensões, do formato, dos materiais, do funcionamento e da expressão plástica das aberturas, nada informando sobre a sua execução, que, como se viu, ficava a cargo de uma mão de obra especializada, nesse caso, de caixilheiros e/ ou serralheiros.

Os desenhos das janelas e portas de correr desenhadas por Heep para o edifício Vicente Filizola, por sua vez, tinham o propósito de aumentar a iluminação das salas de escritório, daí a sua amplitude horizontal, conforme a largura dos ambientes, e vertical, de piso a teto. Intentava-se também melhorar o desempenho térmico dos ambientes com a adoção de quebra-sóis horizontais, recentemente retirados do edifício e no qual controlavam a incidência solar. Percebe-se ainda uma preocupação em alinhavar os elementos de iluminação e ventilação com os de estrutura e vedação, de modo a conformar uma expressão plástica coerente e integral tanto do ponto de vista construtivo quanto estético. Para tanto, os pilares foram desenhados de forma a atender à dupla função de estrutura e engate dos caixilhos e quebra-sóis, sendo resultado do cálculo estrutural do engenheiro e do agenciamento do arquiteto, responsável por compatibilizar os diversos elementos do edifício, suas funções, execução e linguagem. A solução foi orientada pela intenção de conceber uma fachada marcada pelo ritmo desses elementos, em uma tentativa de aproximar arquitetura e engenharia, plasticidade e construtibilidade. 


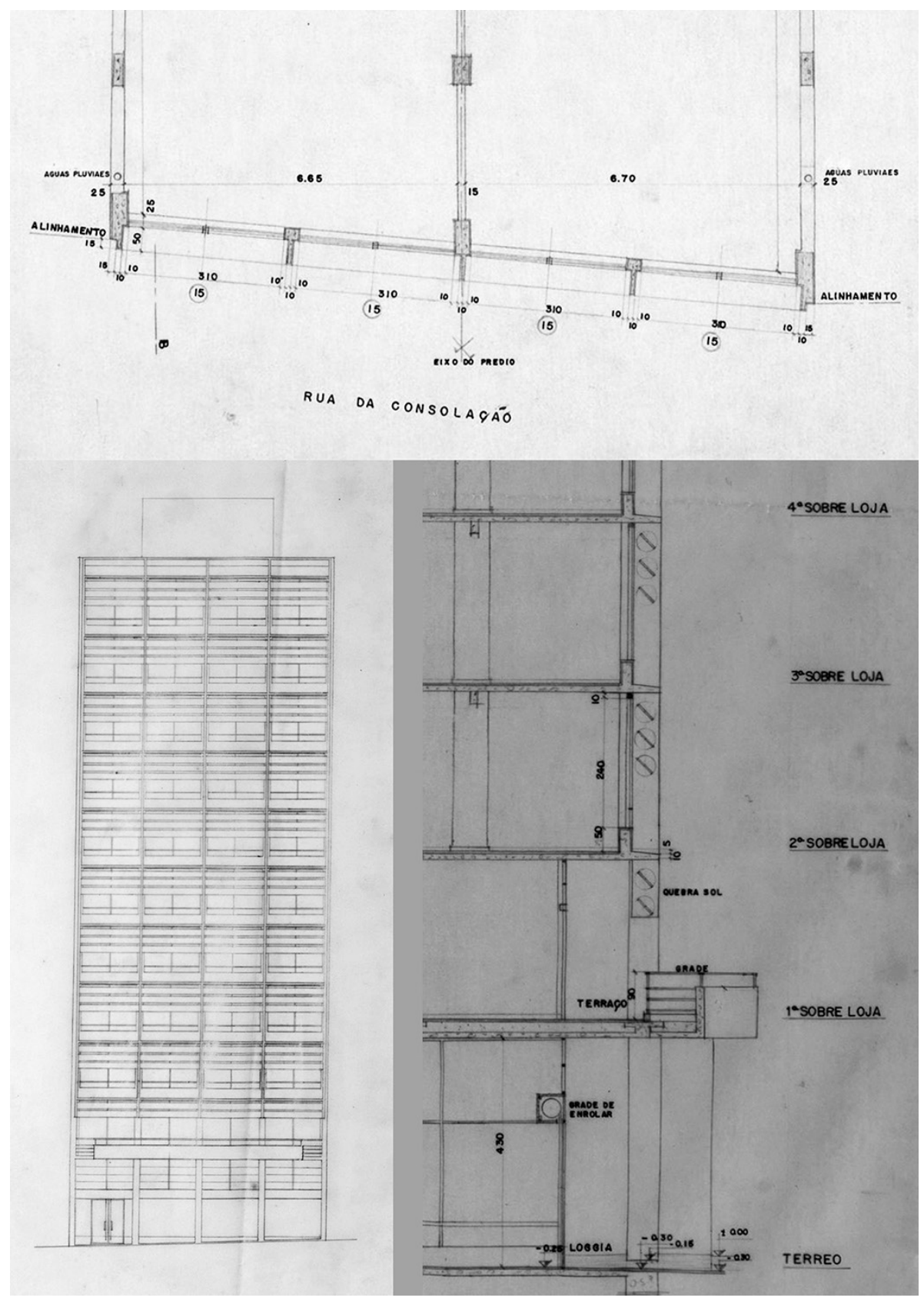

Figura 3: Caderno de Obras n³9 - Igreja de São Miguel Paulista Obras de recuperação, consolidação e restauração - 1939-1940 - p.29. Fonte: Arquivo Fotográfico, IPHAN/SP

maior detalhamento do projeto, portanto, responde aos novos anseios dos arquitetos, às mudanças na sua prática profissional e reestruturação setor da construção civil no Brasil (GITAHY; XAVIER, 2002). Vale apontar ainda que o detalhamento apurado desses e outros elementos se explica pelo fato de que o setor, apesar de sua paulatina mecanização, permanecia bastante artesanal nos anos 1950, sendo grande parte a fatura do edifício realizada em pequenas oficinas especializadas ou no próprio canteiro de obras. 
A relação entre os documentos disponíveis da Coleção Jacques Pilon da Biblioteca da FAUUSP e os problemas históricos que orientaram minha pesquisa de doutorado - a constituição do campo arquitetônico no Brasil; a história de São Paulo e sua arquitetura e a contribuição dos arquitetos estrangeiros para a construção da cidade entre 1930 e 1960 - foram fundamentais para a construção destas análises. Contribuiu para isso uma abordagem teórico-metodológica afinada com a história cultural, atenta à crítica das fontes e acervos de pesquisa e aberta ao diálogo com outros campos do conhecimento.

Neste artigo, como na tese, interessou investigar a obra de Jacques Pilon desde o momento de sua realização até a sua constituição como um documento/ monumento. Nesse processo, não apenas a produção, organização e atuação dos escritórios do arquiteto francês se tornaram objeto de estudo, mas também a conformação de sua coleção, a constituição do acervo no qual seus projetos foram inseridos e os agentes envolvidos em cada um desses momentos.

A análise das fontes documentais na relação com a constituição do campo arquitetônico iluminou os esforços de autonomização da arquitetura em relação à engenharia que implicaram, no Brasil, uma separação entre projeto e obra. No caso de Pilon, esses esforços aparecem claramente nos carimbos do escritório, embora na prática ele tenha mantido vínculos com a atividade imobiliária e construtora ao longo de toda a sua carreira. Tais vínculos ajudam a explicar por que a sua produção demorou décadas para receber atenção por parte dos historiadores da arquitetura, a despeito de ela ter marcado a paisagem da cidade de São Paulo, sobretudo na região central, onde o arquiteto construiu dezenas de edifícios, entre eles marcos importantes como a Biblioteca Mário de Andrade (1935-1942) e a sede do jornal O Estado de S. Paulo (1943-1951). Elas explicam também o envolvimento de Gasperini na doação do acervo de projetos dos escritórios de Pilon para a FAUUSP e, com isso, o esforço deliberado de dar a essa produção um lugar na história. Entretanto, e isso é importante notar, a iniciativa pôde reverberar por conta da revisão das definições do campo arquitetônico e da historiografia da arquitetura, iniciadas na década de 1980, que resultaram na afirmação de outras práticas e vínculos profissionais e da autonomia da história com relação ao projeto.

Ainda com relação ao campo arquitetônico, a análise seriada dos desenhos indicou transformações no exercício profissional, do escritório à obra, com uma maior especialização dos trabalhos do arquiteto e alteração no perfil dos trabalhadores que compunham os canteiros. Essas mudanças repercutiram no projeto, que se modificou também em função de novas formas de conceber a arquitetura, não mais como vestimenta, mas como uma disciplina que procura articular em uma forma única programa, construção e plasticidade.

No diálogo com a história de São Paulo e sua arquitetura, as fontes documentais permitiram refletir sobre os vínculos entre a prática profissional e o 
mercado imobiliário entre os anos 1930 e 1960, momento marcado por um processo de metropolização que envolveu um acelerado aumento populacional, a expansão horizontal da malha urbana articulada com o adensamento vertical das áreas centrais, uma complexificação da sociedade com uma diversificação das atividades econômicas, políticas, sociais e culturais. A diversidade de encomendas recebidas pelos escritórios de Pilon, seja do ponto de vista da escala, seja do ponto de vista da clientela e do programa, respondeu e participou da constituição da metrópole paulistana nesse momento. A intensidade da metropolização aparece na grande quantidade de obras que transformaram o desenho da cidade e atestam a contribuição de Pilon em sua construção, mas também na realização simultânea de vários projetos em seu escritório, cuja dinâmica pode ser recuperada a partir das análises dos carimbos. Tais análises permitiram acompanhar a organização do escritório e suas mudanças ao longo do tempo, assim como o papel e a contribuição de cada um de seus membros, fossem eles proprietários, chefes, arquitetos e desenhistas.

Comparando a sua trajetória com a de outros arquitetos do período, fica claro o nicho de atuação desses profissionais e o quanto a urbanização deu suporte à sua prática, contribuindo ainda para as outras atividades econômicas por eles desempenhadas, como a participação no mercado imobiliário em expansão, no qual se inseriam não só como arquitetos, mas também como investidores. No caso de estrangeiros, como Pilon, isso se tornou um caminho de inserção profissional e social essencial. Inserção essa que, como se viu, foi construída a partir de um conjunto de estratégias reveladas também pela análise dos carimbos do escritório, evidenciando como as atribuições profissionais eram definidas em cada desenho conforme o interlocutor específico, seus valores e expectativas.

Dessa forma, procurando articular a história da arquitetura com outros campos do conhecimento nem sempre a ela relacionados, mas que juntos podem construir uma leitura mais complexa e potente da arquitetura, seja como conhecimento disciplinar, seja como produção, novas hipóteses foram aqui lançadas, iluminando novas e velhas fontes de pesquisa, e contribuindo para os esforços de revisão da historiografia da arquitetura moderna no Brasil. 


\section{REFERÊNCIAS}

ARTIGAS, João Batista Vilanova. Aos formandos da FAUUSP (1955). In: XAVIER, Alberto

(Org.). Caminhos da arquitetura. São Paulo: Cosac Naify, 2004. p. 59-63.

Revisão crítica de Niemeyer (1958). In: XAVIER, Alberto (Org.). Depoimento de uma geração - arquitetura moderna brasileira. São Paulo: Cosac \& Naify, 2003. p. 240-241.

BARBOSA, Marcelo Consiglio. A obra de Adolf Franz Heep no Brasil. 2002. Dissertação (Mestrado) - Faculdade de Arquitetura e Urbanismo, Universidade de São Paulo, São Paulo, 2002.

Adolf Franz Heep. 2012. Tese (Doutorado) - Faculdade de Arquitetura e Urbanismo, Universidade Presbiteriana Mackenzie, São Paulo, 2012.

BARTH, Fredrik. Grupos étnicos e suas fronteiras. In: POUTIGNAT, Phelippe; STREIFFFENART, Jocelyne. Teorias da etnicidade. São Paulo: Editora da Unesp, 1997. p. 185-227.

BAXANDALL, Michael. O olhar renascente: pintura e experiência social na Itália da Renascença. Rio de Janeiro: Paz e Terra, 1991.

BOURDIEU, Pierre. O mercado de bens simbólicos. In: A economia das trocas simbólicas. São Paulo: Perspectiva, 1974a. p. 99-181.

Campo do poder, campo intelectual e habitus de classe. In: A economia das trocas simbólicas. São Paulo: Perspectiva, 1974b. p. 183-202.

Sobre o poder simbólico. In: O poder simbólico. Lisboa: Difel, 1989a. p. 7-16.

Espaço social e gênese das "classes". In: O poder simbólico. Lisboa: Difel, 1989b. p. 133-161.

BRANCO, Ilda Helena Diniz Castello. Arquitetura no centro da cidade edifícios de uso coletivo, São Paulo: 1930-1950. 1988. Dissertação (Mestrado) - Faculdade de Arquitetura e Urbanismo, Universidade de São Paulo, São Paulo, 1988.

CATÁLOGO de desenhos de arquitetura da Biblioteca da FAUUSP. São Paulo: Universidade de São Paulo/Faculdade de Arquitetura e Urbanismo; Vitae - Apoio à Cultura, Educação e Promoção Social, 1988.

CHAFEE, Richard. The Teaching of Architecture at École des Beaux-Arts. In: DREXLER, Arthur (Ed.). The Architecture of École des Beaux-Arts. London: Secker \& Warburg, 1977. p. 61-110. 
CHARTIER, Roger. A história cultural: entre práticas e representações. Lisboa: Difel, 1990.

DERRIDA, Jacques. Archive Fever: A Freudian Impression. Chicago: The University of Chicago Press, 1995.

DURAND, José Carlos. A profissão de arquiteto: estudo sociológico. Rio de Janeiro: CREA $5^{\mathrm{a}}$ Região, 1974.

. Arte, privilégio e distinção: artes plásticas, arquitetura e classe dirigente no Brasil, 1855/1985. São Paulo: Perspectiva; Editora da Universidade de São Paulo, 1989.

FICHER, Sylvia. Os arquitetos da Poli: ensino e profissão em São Paulo. São Paulo: Edusp, 2005.

FRANCO, Tiago Semene. A trajetória de Jacques Pilon no centro de São Paulo: análise das obras de 1940 a 1947. 2009. Dissertação (Mestrado) - Faculdade de Arquitetura e Urbanismo, Universidade Presbiteriana Mackenzie, 2009.

GITAHY, Maria Lucia Caira; XAVIER, Paulo César Pereira (Orgs.). O complexo industrial da construção e habitação moderna, 1930-64. São Carlos: RiMa, 2002.

GUTIERREZ, Rámon. Os arquivos de arquitetura no contexto Latino Americano. In: CASTRIOTA, Leonardo Barci (Org.). Arquitetura e documentação. Belo Horizonte: IEDS, 2011. p. 29-52.

JULIANI, Maria Rosa de Oliveira. Ideologia, estado e mercado: três aspectos da profissão do arquiteto em São Paulo. In: GITAHY, Maria Lucia Caira; PEREIRA, Paulo César Xavier (Orgs.). O complexo industrial da construção e a habitação econômica moderna, 1930-1964. São Carlos: RiMA, 2002. p. 143-161.

LE GOFF, Jaques. Documento/Monumento. In: História e memória. Campinas: Editora da Unicamp, 1990. p. 462-478.

LEMOS, Celina Borges et al. (Org.). Escola de arquitetura da UFMG: lembranças do passado, visões do futuro. Belo Horizonte: EA/ UFMG, 2010.

LIRA, José Tavares Correia de. A história e o fazer da arquitetura. Desígnio, São Paulo, v. 11/12, p. 11-18, 2011.

LOPES, João Marcos; LIRA, José Tavares Correia de (Orgs.). Memória, trabalbo e arquitetura. São Paulo: Edusp; CPC/USP, 2013.

MARQUES, Eliana de Azevedo. Serviço da Biblioteca e informação da FAUUSP. Pós, São Paulo, n. 20, p. 226-238, dez. 2006. 
MENESES, Ulpiano Toledo Bezerra de. Fontes visuais, cultura visual, história visual. Balanço provisório, propostas cautelares. Revista Brasileira de História. São Paulo, v. 23, n. 45, p.11$36,2003$.

MONTANER, Josep Maria. Ensino de arquitetura. In: ENCONTRO EDUCAÇÃO E SOCIEDADE, I., São Paulo, 2014. Anais... São Paulo: Editora da Cidade, 2014. p. 30-63.

NIEMEYER, Oscar. O problema social na arquitetura (1955). In: XAVIER, Alberto (Org.). Depoimento de uma geração - arquitetura moderna brasileira. São Paulo: Cosac \& Naify, 2003. p. 184-188.

Depoimento (1958). In: XAVIER, Alberto (Org.). Depoimento de uma geração arquitetura moderna brasileira. São Paulo: Cosac \& Naify, 2003. p. 238-240.

NOBRE, Ana Luiza. Fios cortantes: projeto e produto, arquitetura e design no Rio de Janeiro (1950-1970). Tese (Doutorado) - Departamento de História, Programa de Pós-Graduação em História Social da Cultura, Rio de Janeiro, 2008.

PARETO JÚNIOR, Lindener. Pândegos, rábulas, gamelas: os construtores não diplomados entre a engenharia e a arquitetura (1890-1960). 2016. Tese (Doutorado) - Faculdade de Arquitetura e Urbanismo, Universidade de São Paulo, São Paulo, 2016.

PASSOS, Maria Lúcia Perrone (Org.). Os campos do conbecimento e o conbecimento da cidade. São Paulo: Museu Paulista da Universidade de São Paulo, 1992. (Cadernos de História de São Paulo, 1).

PEREIRA, Gustavo. Christiano Stockler das Neves e a formação do curso de arquitetura no Mackenzie College. Um estudo sobre a disseminação dos métodos da "École des Beaux-Arts de Paris" e das "Fine-Arts Schools" norte-americanas. 2005. Dissertação (Mestrado) - Faculdade de Arquitetura e Urbanismo, Universidade Presbiteriana Mackenzie, São Paulo, 2005.

RIBEIRO, Demétrio; SOUZA, Nelson; RIBEIRO, Enilda. Situação da arquitetura brasileira (1956). In: XAVIER, Alberto (Org.). Depoimento de uma geração - arquitetura moderna brasileira. São Paulo: Cosac \& Naify, 2003. p. 203-207.

ROCHA-PEIXOTO, Gustavo. A estratégia da aranha. Rio de Janeiro: Rio Books, 2013.

ROSSETTO, Rossella. Produção imobiliária e tipologias residenciais modernas. São Paulo 1945/ 1964. 2002. Tese (Doutorado) - Faculdade de Arquitetura e Urbanismo, Universidade de São Paulo, São Paulo, 2002.

SAKURAI, Tatiana et al. Acervo David Libeskind MAB/ FAUUSP: constituição por meio do ensino, aprendizado e difusão. In: SEMINÁRIO DOCOMOMO_BR, O CAMPO AMPLIADO DO 
MOVIMENTO MODERnO, 11., Recife, 2016. Anais... Disponível em: <http://www. seminario2016.docomomo.org.br/artigos_apresentacao/sessao\%2012/DOCO_PE_S12_ SAKURAI_BRITO_ULIANA_MARQUES.pdf>. Acesso em: 15 ago. 2016.

SÃO PAULO, os estrangeiros e a construção da cidade. Faculdade de Arquitetura e Urbanismo da Universidade de São Paulo. [s.d.]. Disponível em: <http://estrangeiros.fau.usp.br/page. php?name=home>. Acesso em: 15 out. 2016.

SCHORSKE, Carl E. Viena fin-de-siècle: política e cultura. São Paulo: Companhia das Letras, 1988.

SILVA, Joana Mello de Carvalho e. O arquiteto e a produção da cidade: a experiência de Jacques Pilon, 1930-1960. São Paulo: Annablume; Fapesp, 2012.

ULIANA, Dina Elisabete. A Biblioteca da Faculdade de Arquitetura e Urbanismo da Universidade de São Paulo. Arqu. Urb., São Paulo, n. 9, p. 9-27, jan.-jun. 2013. Disponível em: <http://www. usjt.br/arq.urb/numero-09/03-dina-elisabete.pdf>. Acesso em: 15 ago. 2015.

WARCHAVCHIK, Pilon. Rino Levi: três momentos da arquitetura paulista. São Paulo: Funarte; Museu Lasar Segall, 1983.

WAISMAN, Marina. O interior da história: historiografia arquitetônica para uso de latinoamericanos. São Paulo: Perspectiva, 2013.

WEIMER, Günter. Arquitetos e construtores no Rio Grande do Sul. Santa Maria: Editora da UFSM, 2004.

Arquitetos e construtores rio-grandenses na colônia e no império. Santa Maria: Editora da UFSM, 2006.

Artigo apresentado em 28/03/2016. Aprovado em 27/12/2016. 